PALEO

Revue d'archéologie préhistorique

$27 \mid 2016$

Varia

\title{
Paleohistory of an Aurignacian bison skull from Régismont-le-Haut (Hérault): from nature to value
}

Jean-Philip Brugal

\section{(2) OpenEdition \\ 1 Journals}

Electronic version

URL: http://journals.openedition.org/paleo/3237

DOI: 10.4000/paleo.3237

ISSN: 2101-0420

Publisher

SAMRA

Printed version

Date of publication: 30 December 2016

Number of pages: 62-82

ISSN: 1145-3370

\section{Electronic reference}

Jean-Philip Brugal, « Paleohistory of an Aurignacian bison skull from Régismont-le-Haut (Hérault):

from nature to value », PALEO [Online], 27 | 2016, Online since 01 June 2018, connection on 07 July 2020. URL : http://journals.openedition.org/paleo/3237 ; DOI : https://doi.org/10.4000/paleo.3237

This text was automatically generated on 7 July 2020 .

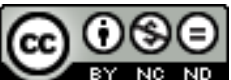

PALEO est mis à disposition selon les termes de la licence Creative Commons Attribution - Pas d'Utilisation Commerciale - Pas de Modification 4.0 International. 


\title{
Paleohistory of an Aurignacian bison skull from Régismont-le-Haut (Hérault): from nature to value
}

\author{
Jean-Philip Brugal
}

I wish to sincerely thank F. Bon and R. Mensan, directors of the programmed field operations at Régismont-le-Haut, as well as all their team, in particular S. Costamagno and D. Kuntz, for inviting me to study this particularly interesting skull, which is conducive to original sets of assumptions. The mission in Poland (French-Polish programme, MAE, 2007) was possible thanks to Ph. Fosse. Thanks to J. Speth for our transcontinental exchanges on our (or one of our) favourite animal(s), the bison. Thanks to F. Delpech and J.-C. Castel for their attentive, and necessary proofreading.

1 Régismont-le-Haut is one of the rare early Upper Palaeolithic (Aurignacian) open-air sites in Europe with such well-conserved remains and structures. It is located in the Languedoc plains and has yielded considerable archaeological material (lithic remains, colouring materials, shells, etc.), associated with abundant occupation dwelling, including in particular, several fire structures spread over a surface of about $600 \mathrm{~m}^{2}$ (Bon, Mensan et al. 2007, 2008; Anderson et al., submitted). Mineral materials are well preserved although bone remains are generally poorly conserved, apart from a surprisingly well-preserved bison skull. This contribution focuses on this skull and assesses its taphonomic context and anthropological significance, as well as the taxonomic status of large bovids from the end of the Upper Pleistocene.

\section{Discovery background}

Programmatic excavations have been carried out at the site of Régismont-le-Haut (Poilhes, Hérault) since 2000, directed by F. Bon (Université de Toulouse Jean Jaurès) and R. Mensan (Bon, Mensan et al. 2007, 2008). This open-air site is located on the foothills of the hill of Ensérune (of Miocene age), within the Biterrois Plain, and contains an Aurignacian industry, which is difficult to accurately situate in time 
(Recent Aurignacian?). The site records one or several (seasonal?) occupations of an hunter-gatherer group, associated with numerous structures, in particular, hearths ${ }^{1}$. The sediment is formed of sandy-silty colluviums, in relation with a channel, which is not conducive to the conservation of organic remains (e.g., bones and teeth). Indeed, most of the collected bone fragments are "ghost" remains, apart from small charred remains or those from denser accumulations, like near the hearths XII-XVI (sector S56). These are non-identifiable dental micro-fragments and small diaphyseal fragments with a cortical thickness corresponding to a large ungulate (size of the bison or horse).

However, in 2005, in sector S72, a bison skull was discovered (fig.1), just beside its first cervical vertebra (atlas), followed by a poorly conserved hip bone, from the same genus and the same sector. Clearly, the bone mass represented by this element could partly explain why it was better conserved than the other smaller and very dispersed bone remains. Several dental fragments, as well as two upper left molars, were found before the discovery of the skull in the same zone. This skull was found three meters away from a hearth (F. XIV), surrounded by several lithic remains and pigments. These lithic objects comprise quartz debitage, including a flake discovered immediately beside the skull. The hypothesis of a butchery tool has been proposed, but could not be corroborated by the functional study (by M. Araujo) due to the absence of diagnostic traces.

4 Therefore, only large elements seem to have been conserved, and the dental material is practically absent, which illustrates the aggressive nature of the sedimentary environment. However, the geoarchaeological study points to the good structural conservation of human occupations, on a flat area exposed to marginal erosion (Bon, Mensan et al. 2007, 2008), suggesting limited movement of the remains. The integrity of the combustion structures confirms this hypothesis, which is an important aspect for the taphonomic interpretation of the bison skull (cf. infra). 
Figure 1 - General view of the site of Régismont and location of the bison skull, in situ view (September, 2005: basal/ventral view).

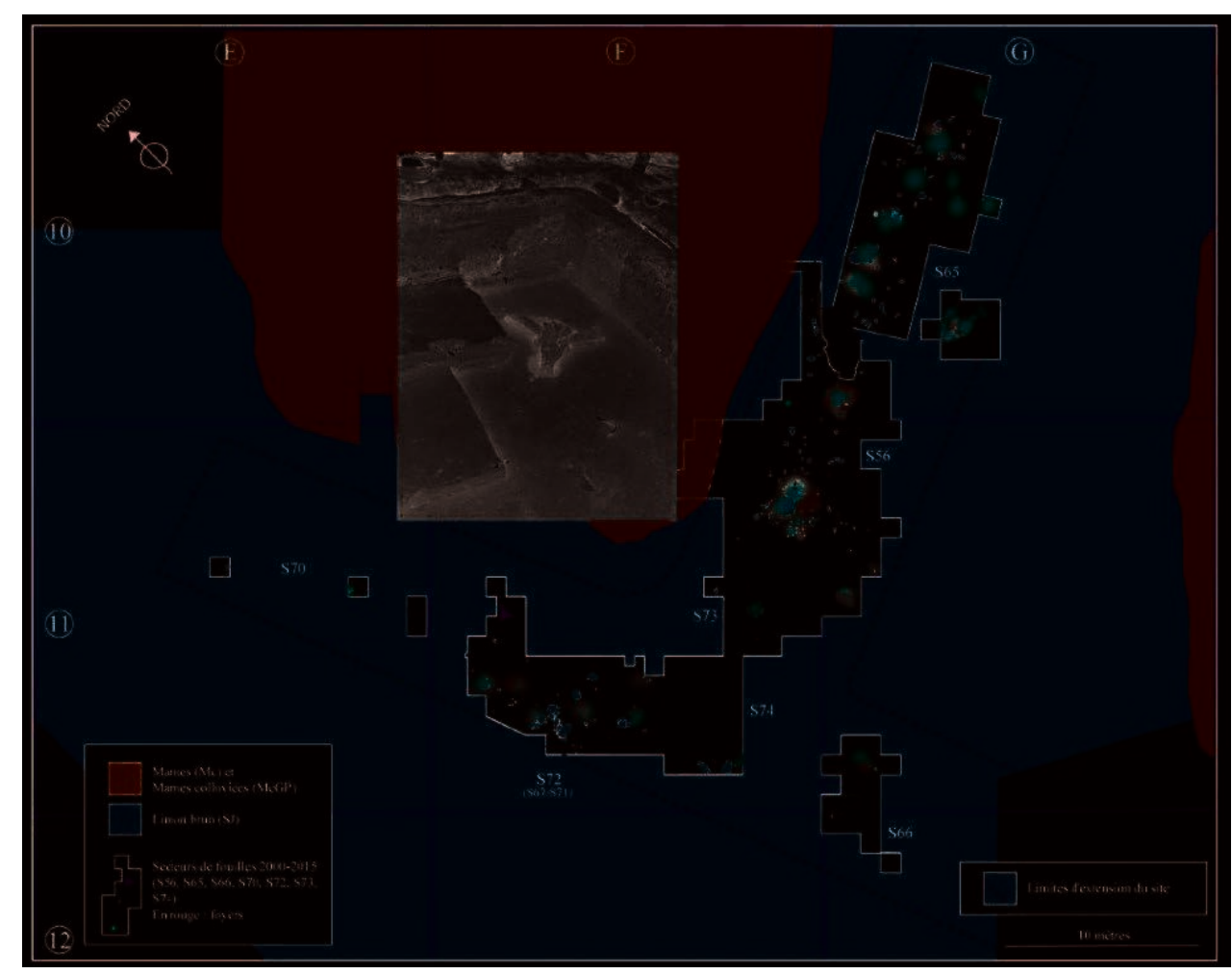

(Photos F. Bon)

5 After the discovery of the skull, a first field intervention in September 2005, at the invitation of F. Bon and S. Costamagno, enabled us to attribute the specimen to the genus Bison and to carry out the first observations and measurements. The skull was overturned in a slightly oblique position, showing its basal surface, with the atlas nearby. This vertebra is poorly preserved, preventing a morphometric study. After that, the skull was carefully plastered, brought to the laboratory in Toulouse, then restored (Kuntz 2006), and turned over so that it now presents its dorsal side (fig. 2). This new orientation enabled us to take a series of measurements in June 2006 to complete or clarify the first measurements. These sometimes overlap and do not always coincide with the same dimensions taken in 2005; and some of them were then averaged. In any case, considering the general state of the skull, the measurements are sometimes only estimated, which is often the case for published fossil skull bison from European sites. 
Figure 2 - Excavation and restoration (June 2006, basal/frontal view).

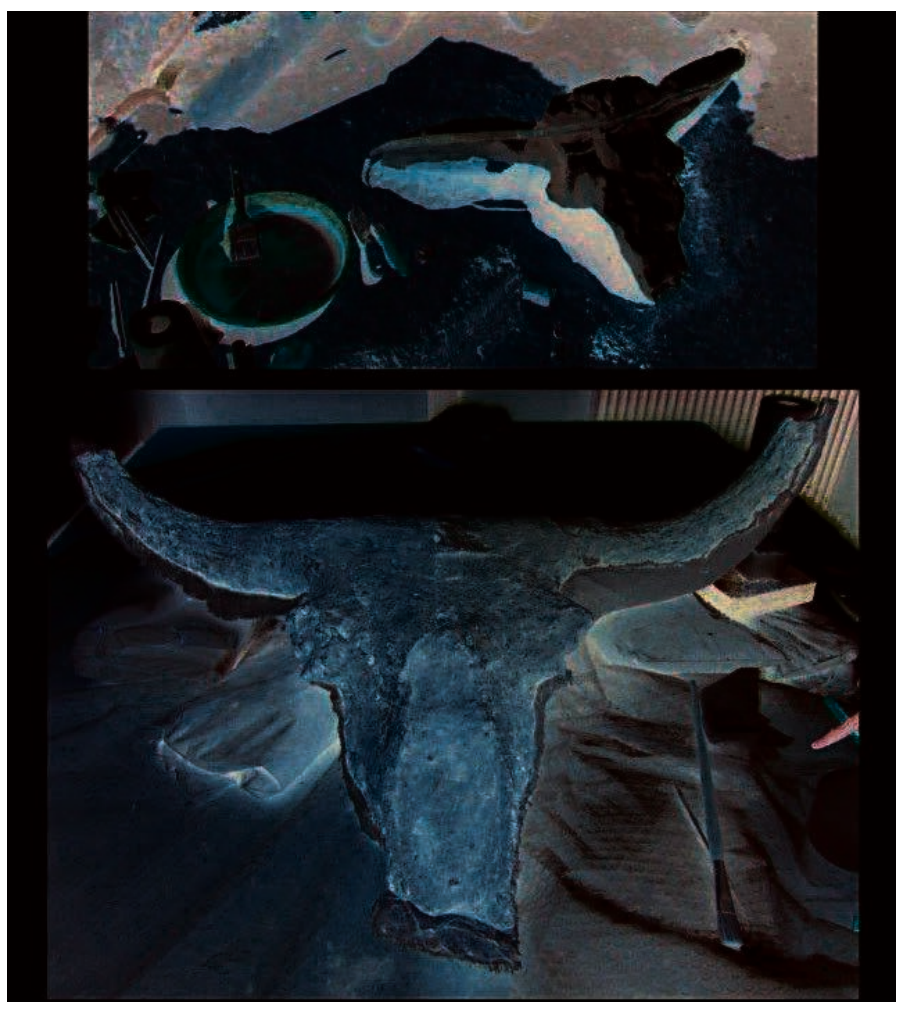

(Photos F. Bon)

\section{Description and first interpretation}

6 The skull is relatively complete. However, the following parts are missing: the anterior dorsal part (lower frontal, nasals and anterior part of the incisor bone or premaxillary), the tips of the horn-cores, the upper teeth (small fragments of molar enamel were found near the maxillary, or slightly above the skull when it was discovered). The nuchal surface is altered with a poorly conserved basioccipital and abraded occipital condyles, as well as a nuchal crest. The missing anterior part is the most fragile and corresponds to the region where the sutures remain open for longest (nasal, lower frontal), even on adult animals (cf. fig. 3 to compare them with older European bison specimens). However, the whole skull is in relatively good condition, not compressed or deformed, with variable bone surfaces (cf. infra); rare fissures (on the frontal bone which appears to be thick) indicate slight sedimentary compaction. The cranial sutures are not visible, all closed, which indicates the adult stage of the animal and could also explain its relatively good general conservation. Sediment is present in the cerebral cavity. The overall skull size and its solid aspect point to an attribution to a male (cf. infra): in comparison, female skulls are often thinner and fragile with less compact horn-cores (the sutures close when the reproduction function is finished, at about 13-15 years old, until 20 years old). For males, these sutures close at about 6-7 years old (Flerow 1979; Vasiliev 2008), which is why it is more common to discover male bison skulls than female skulls, in relation to this greater robustness, particularly in alluvial contexts (Vasiliev 2008: alluvial sites of Western Siberia). 
Figure 3 - Photos of modern male Bison bonasus (frontal/dorsal view) (cf. tab. 4; $n^{\circ}$ MRS, Poland: top L: 161142, R: 162519; bottom L: 163751, R: 167742).
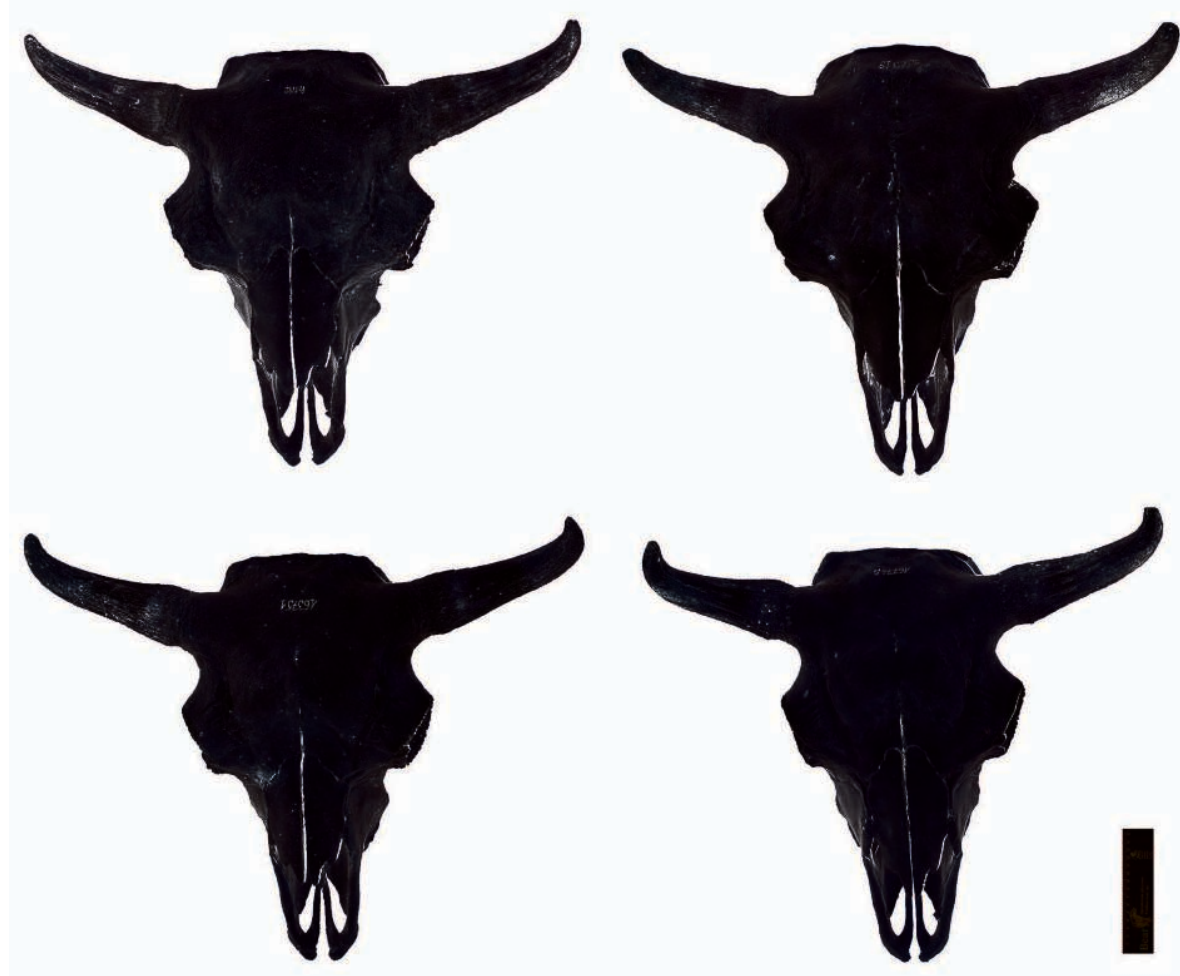

(Photos Ph. Fosse)

7 From a taphonomic viewpoint, several points can be noted: the presence of the atlas associated with the skull indicates a connection, showing that these two elements remained together throughout their "history", before, during and after burial. However, they are not in strict anatomic connection and we can assume that a subaerial exposure detached the ligaments and that the atlas fell, and moved slightly away from the skull, before adopting its definitive position. In this respect, it is interesting to notice that the remains were covered by about five centimetres of sediment before the atlas fell. The base of the atlas is thus slightly higher than the base of the skull, which corroborates hypotheses pointing to a rapid and natural burial (i.e., the skull was not buried by humans, for example). However, the fact that the teeth are practically all missing reveals sufficient exposure for most of them to loosen or crack, and fall from the skull, and to disappear by sedimentary digestion (physico-chemical, cryogenic cycle). In any case, the good overall conservation of the skull implies that although it may have been exposed for a period of several years, it was buried rather quickly, resulting in its good conservation. If this had not been the case, the most fragile, often exposed parts (in relation to the height of the skull) would have disappeared, in particular the spongy horn-cores. This is observed in North American Paleoindian sites where the upper part of skulls (with the "horns" is often decapitated or obliterated, after a relatively slow burial (Todd and Rapson 1999: fig.4, p.490) and a long period of exposure. It is thus possible to postulate that burial results from one (or several) event-type(s), such as colluviation and rather thick and rapid sedimentary deposits. Lastly, after the visual observation of the exposed parts (in the field and in the lab), and in spite of some alteration of the surfaces (sometimes with a film-type 
coating), we did not record any specific traces of anthropogenic origin (cut marks). A depression zone is observable between the horn cores on the left frontal surface, apparently resulting from natural (sedimentary) causes, but no fissures appear on these surfaces.

The origin of this element has yet to be elucidated, and two, partly antagonistic hypotheses can be advanced. The first suggests that this bison skull corresponds to a male individual hunted and killed by the Aurignacians. The second considers it as a remain collected from or just beside the camp.

In the first of these hypotheses, the head of the animal would have been removed (between the atlas and the axis) and the mandible separated (with removal of the cheek and the tongue (?), which are very nutritious parts). On the other hand, the brain does not appear to have been retrieved, judging by the fact that the cephalic cavity is intact, and the presence of the atlas blocks access through the occipital foramen. Yet, besides the dietary value of the brain, there is no evidence of its use for certain stages of hide processing at Régismont, even though this activity is widespread at this site, as shown by the type of tools and use-wear. However, in the context of bison hunting, a single individual can be slaughtered, or animals can be slaughtered occasionally, but other examples point to the more widespread or recurrent slaughter of this gregarious species (collective hunting where several specimens are slaughtered, or regular slaughter throughout time) (Brugal et al. 1999). In such a context, the head of one individual, which would then become a skull, would have been intentionally left aside, leaving the still usable resource, possibly for a different use.

Skulls are, by nature, valued hunting trophies, and it is not rare, and even relatively frequent, to conserve, exhibit and use them. They are sometimes decorated in traditional societies, as shown by many ethnographic examples, in particular in North American 'bison societies' (e.g., Garrait-Bourrier 2006). Paleoindian archaeological examples are also numerous: painted bison skull (Bement 2003; and see Nicholson and Nicholson 2007), structure of skulls (Frison 1971; Reher and Frison 1980).

11 The Régismont skull corresponds to a large-sized specimen, representing a fully physiologically mature male adult and a quality prey, which is not always easy to hunt and kill. In this context, we suggest that this skull (with its atlas) could have been hung up, or at least placed in an elevated position, at the end of a wooden stake that disintegrated over time and made the skull fall, dispersing the teeth and the atlas. This practice was observed for the first time in early Upper Palaeolithic societies, and is very plausible for anatomically modern humans. It would have had a highly symbolic function.

12 The second possible origin of this skull is that it may have been collected from around the site, or even gathered at the site itself. The skull may have been found defleshed and skinned, the mandible removed, with some of the teeth already loose, the cephalic part intact and with no apparent anthropogenic traces. The presence of the atlas is linked to the existence of a very strong ligamentary connection between the skull and the first cervical vertebra (Hill 1979) and allows us to partly infer the interval of time between death and burial (Hill and Behrensmeyer 1984). In our case, the estimated exposure time is between 2 and 4 years; the skull was beginning to dry, until the final loss of the atlas (not far from the skull) and rapid sedimentary covering. The presence of this skull in this place could be a sign of the existence of this gregarious species in this sector, and although it may not represent an omen, it may have been gathered and 
used for purposes other than dietary requirements. The probably symbolic practice, based on hunting, mentioned above, is very likely in this context. However, given the good overall condition of this element, with no trace of exfoliation or surface weathering, the hypothesis of simple collection seems to be more uncertain and we will retain the first hypothesis, that of a specific portion taken from a slaughtered animal to be exhibited.

\section{Paleontological study and taxonomy}

The cephalic Bison skeleton differs from the Bos skeleton in the following ways, corresponding to the main evolutive trends of the Bovini (Gromova 1932, 1935; Pilgrim 1947; Bohlken 1958; Geraads 1992; Pfeiffer 1999): the bison presents a significant widening of the frontal surface without total discharge of the parietal region towards the occipital surface (primitive character); the frontal is relatively shorter than for Bos; the parietal participates pro parte in the formation of the cranial vault in the bison; the occipital is relatively wider and lower and the occipital protuberance is more developed behind the horn-cores; the posterior opening of the temporal fossa is larger; in most cases, the more prominent orbits are oriented towards the front and the top. The overall skull morphology of the aurochs (and derived species) is longer and narrower than for the bison, which has a wider and more compact skull. The cross-section of bison horn-cores is more or less (sub)triangular to oval (horizontal diameter superior to the vertical diameter at the base) and develops first of all slightly towards the base and the rear, then clearly towards the top, with ptips more or less tilted towards the rear (slight torsion); the curve is non-helicoidal and lastly, for old specimens, marked longitudinal grooves cover the surface of the horn-cores.

On a species level, the overall skull morphology of fossil bison, priscus and schoetensacki (Flerow 1975, 1976; Sala 1987) is comparable to that of present-day bonasus and bison (Empel 1962; McDonald 1981). The width and curve of the frontal vary depending on the dimensions of the horns. These vary a lot within each species, as regards shape, length, and the curve, in relation to the sex and age of specimens. However, we can make several observations for the horn-cores: for B. priscus, they are oriented downwards at their departure from the skull, they curve towards the sides or towards the rear and go beyond the skull; they are rarely spiral-shaped. In B. schoetensacki, the horns are shorter and heavier, they narrow from the base to the top, the base is flattened and the cross-section becomes more circular towards the distal $2 / 3$, they curve slightly to the front for the proximal $1 / 3$, then towards the top and in the final $1 / 3$, towards the back, the horns are relatively rectilinear (Brugal 1994-95). The present-day species are similar to the steppe bison, B. priscus, with several differences, namely shorter horns and a relative smaller body size, and also head positon, lower for bison (grazer) than bonasus (mixed-feeder to browser).

The Régismont skull (fig. 2) is typical of Bison, similar to the priscus lineage or assimilated (cf. infra). The horns are rather impressive, laterally oriented (angle of about $80^{\circ}$ with the sagittal plane) and slightly tilted towards the back and downward, before curving and facing upwards, then towards the rear at the points, with a very slight twist. The female horns are less heavy, more rectilinear and laterally oriented, and do not tilt towards the base (Prat et al. 2003). The cross-section of the Régismont horns is sub-oval at the base, whereas it is more circular for example on B. priscus from 
Habarra (Prat et al. 2003: fig. 25-26) or Gandil (Griggo 2014). The section is variable (subcircular, suboval and even - more rarely - subtriangular) on present-day European bison (Brugal, pers. obs.). There do not seem to be any or many grooves (inferior surface), which is a characteristic rather linked to age. The protuberance between the horns, at the frontal level (nuchal view) is not very marked. The orbits are strongs , tubular and quite prominent, slightly oriented downward. The overall morphology is thus similar to that of modern European bison (fig. 3), although the latter have shortened horns and more accentuated frontal humps.

Sexual dimorphism is marked for bovines; the female is smaller in size than the male. Many studies (e.g., Gromova 1932, 1935; Flerow 1979; McDonald 1981) show that female horns are considerably shorter than male horns, and sometimes curve differently. In addition, there is a great individual variability, related to the age of individuals and seemingly to the categories and nutritive qualities of the diet. These observations and this very marked dimorphism between sexes, must imperatively be taken into consideration for studies of this group of large bovidsboth for the cranial and the appendicular skeleton (e.g., Brugal and Fosse 2005).

This morphological variability is an adaptive capacity to changing environmental conditions, and is reflected in metric variations; the measurements taken on male specimens are higher than those for female specimens. In general, fossil skulls are not very frequent in collections as they are more vulnerable to alteration and destruction. From a morphometric point of view, the dimensions are often estimated, and are thus approximative. In addition, in the case of Régismont, some measurements could not be taken as it was impossible to manipulate this imposing element (and also due to altered zones). Let us recall that the skull now lies on its underside (exposing a frontal) in a plaster shell (fig. 2): in particular, measurements of height, or basal length, could not be taken and others could only be estimated (noted with an e.= estimation in tables 1-3 ab).

The bison shows a wide geographic and chronological distribution, and covers all of Eurasia and North America. We have however confined our biometric comparison to Eurasia with a relatively limited taxonomic and chronological spaces. Tables 1-3 a-b compile several data on the cranial dimensions from the Upper Pleistocene sites of Western Europe (France, Belgium), and beyond, from Siberia, with forms attributed to B. priscus priscus, to which we have added data on the European bison, B. bonasus, the Wisent (tab. 4). North American bison (priscus/crassicornis, antiquus, occidentalis, bison, athabascae...) are not taken into consideration here. This table does not pretend to be exhaustive: a first reading reveals the disparity in the datasets with, as we noted above, approximate measurements. These are most often isolated specimens and discoveries (apart from the series from Western Siberia). These data thus limit global analyses and graphic illustrations.

The only available length for the Régismont skull is the condylo-basal length (measurement 2), estimated at $495 \mathrm{~mm}$, which is inferior to that of a male B. priscus from Habarra (A55-B1), estimated at $597 \mathrm{~mm}$. In contrast, this dimension is similar to that of B. bonasus males: $(n=5) 480-520$, average of $507 \pm 18.6$. In this set of measurements, the Riverenert skull (Ariège) shows the highest values in our sample. This exceptional skull has been described as B.priscus gigas (Crouzel, Manenc, Revel 1982), and is undoubtedly the oldest element in this series, probably of Middle Pleistocene age. 

(respectively maximal w. at the orbits and $\mathrm{w}$. of the frontal between the orbits and horns) are generally comparable between species but show more marked sexual dimorphism (fig. 4), with higher values for males. There is some overlap between the two taxa, but the priscus from Siberia shows the highest values. The minimal width between the base of the horns (m.31) and the minimal width below the orbits (m.34) are also higher for priscus (similar to Régismont and the Belgian sites) than for male bonasus, whereas the width at the Premaxillary-Nasal limit is similar to that of modern specimens. The dimensions of the orbits of the Régismont skull are greater, but this may be due to the use of slightly different measurement techniques (taking measurements at the interior vs the exterior of the orbits). The length of the horncores (m.47) is much greater for priscus than for bonasus. In the same way, the distance between the points (apex) is greater, in particular for priscus males, where it is close to and in excess of $1 \mathrm{~m}$, which is comparable to Régismont (apart from the Riverenert skull, with a span of $2 \mathrm{~m}$ !); the male bonasus show values ranging between 52 and $65 \mathrm{~cm}$ (nearly half less). Finally, the dimensions of the horn-cores themselves are relatively higher for priscus than bonasus (fig.5); however, the values for priscus females are still similar to bonasus males. The morphology of the cross-sections is also quite variable, and Régismont, like the specimens from Siberia or Belgium, shows rather flattened circumferences in the dorso-ventral direction, and presents a more oval-shaped section, which appears to be a more masculine characteristic.

In sum, the morphology of the Régismont skull clearly indicates a male adult bison. The cranial dimensions are rather closed beetween some of the Upper Pleistocene priscus and present-day bonasus specimens, but the horn-cores are much more developed on the fossil species. This variation may also be found in parietal representations (Fritz and Tosello, pers. comm.). However, the consideration of sex on one hand, and age, on the other (ontogenetic age but also chronological) tends to complicate this schema and to emphasize a high variability of the specimens. In this way, we observe a morphometric proximity between the Upper Pleistocene bison and those from the Holocene. The taxonomy of the large bovids (Bovini), in particular the Bison genus (or sub-genus for some: Groves 1981; Wall, Davis, Read 1992; Hassanin, et al. 2013; Soubrier et al. 2016), the phyletic relations between fossil and modern species and their evolutionary dynamics, are still ambiguous and are still widely debated. This is pro parte in relation in particular with the very high geographic and chronological distribution of these taxa. They are present in the Eurasian zone, at least from the Lower Pleistocene. Several recent molecular studies (based on nuDNA and mtDNA) clarified several points, such as the paraphyly between Bos and Bison, or the monophyly of Bison, but also to show high genetic variability, based on modern and fossil taxa (e.g., Hassanin et al. 2013 and bibliography herein). In this way, another form of bison would coexist - or succeed - to the steppe bison during the Upper Pleistocene, which is a comparable form or clade to the present-day European bison (Cooper et al. 2015; Soubrier et al. 2016; Massilani et al. 2016). The origin of B.bonasus would be a hybridization (introgression) between the steppe bison and the aurochs before $120 \mathrm{ky}$ (Soubrier et al. 2016), or perhaps even earlier (Massilani et al. 2016). In Central Europe; this species would be intermittently present since at least $50 \mathrm{ka}$.

These results raise the question of the taxonomical determination of the bison discovered in Western European Palaeolithic sites, as well as the type (species) of bison 
represented in parietal or portable art; some authors consider that two forms of species would be present (Fritz and Tosello, pers. com.; Spassov and Stoytchev 2003). The question remains open, and morphofunctional approaches (2D, 3D) require further development, for fossil and modern material (see for example, Vasiliev 2008 on metacarpals), in order to take account of the existence of different taxa ${ }^{2}$.

In the light of these data and parameters, which taxon does the Régismont-le-Haut skull belong to? Its morphology allows for a clear attribution to Bison - or Bos (Bison) and its cranial proportions place it within the Upper Pleistocene and Holocene priscusbonasus forms. In addition, like other Eurasian specimens attributed to the steppe bison B. priscus ssp., the size of horn-cores of the Régismont skull are large . We will thus identify the Régismont bison with this species, even with some reserve . Indeed, we could envisage that the early B. bonasus, present at the end of the Pleistocene, also had much larger horns than the present-day representatives of this species. This study thus provides us with the opportunity to point out that the equation (Upper) Pleistocene bison equals B. priscus is perhaps no longer so obvious. The evolution of bison during the course of the Pleistocene is marked by a decrease in body size, with eco-climatic variations (ecotypes). On average, the populations from the end of the Pleistocene seem to be the same size as present-day European bison: sites of Willment' Pit or Shropham in England (Brugal, 1999: fig.3, based on the lengths of metapodials), and Siréjol, Habarra or l'Arquet in France. But are these really priscus? Indeed, the bonasus clade has been identified in the sinkhole (aven) site of l'Arquet in the Gard, with a sequence dated between 45 and $26 \mathrm{ka}$ (Gamberi et al. 2011; Massilani et al. 2016).

Table 1-3 - Measurements $(\mathrm{mm})$ of Bison skulls (correlation between measurements taken by Prat et al. 2003 and Van den Driesh 1976). e.= circa, $M=$ male, $F=$ female, L=length, l=width, ht=height, dist. =distance, $\mathrm{DAP}=$ antero-post diameter, $\mathrm{DVD}=$ dorso-ventral diameter, perim=perimeter. (1) Griggo 2014: Early Dryas; measurements taken from a partial reconstruction (noted e.) (2) in Prat et al. 2003: Habarra (14500+-260 ans BP, Gif7106), Gr.Bison (20 830+-710 ans BP, Ly2452), Espiet (Recent Würm), Riverenert (n.d.), and Rhine, Vistula and Lutachha after Degerbol and Iversen 1945. (3) Germonpré (1993): Belgian sites; EW=Early Weichselian; MW=Middle Weichselian. (4) Vasiliev 2008: sites from Western Siberia . (5) Brugal, pers. data (Mammal Res. Institute, Pologne, 2009) and table 2.

Table 1a - Fossil bison skulls from France and Northern Europe. Dorsal, lateral and nuchal views.

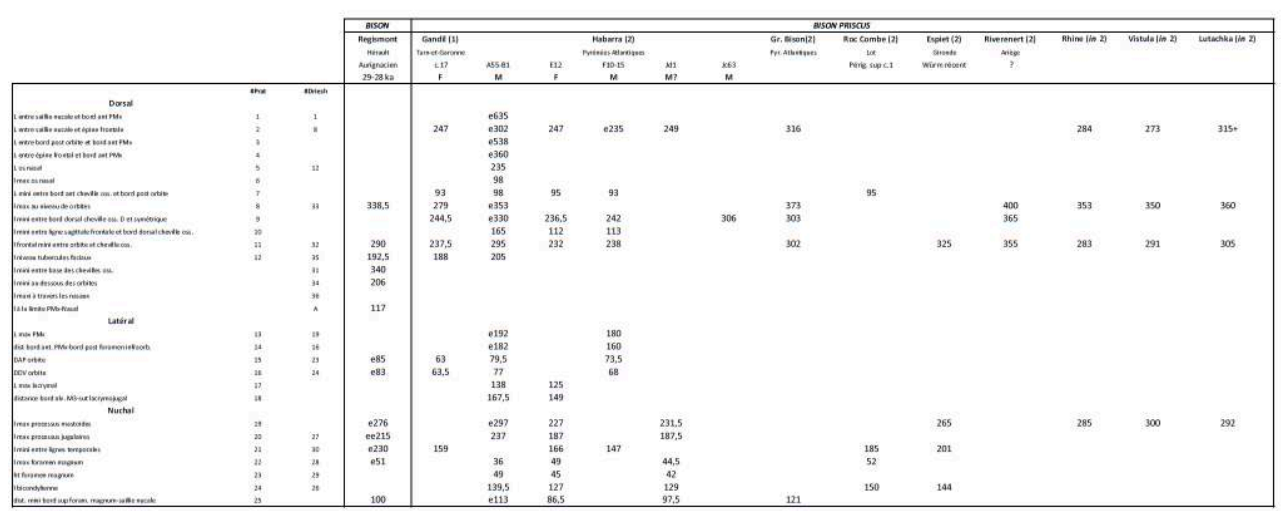


Table 1b - Fossil bison skulls from France and Northern Europe. Ventral view and horn-core.

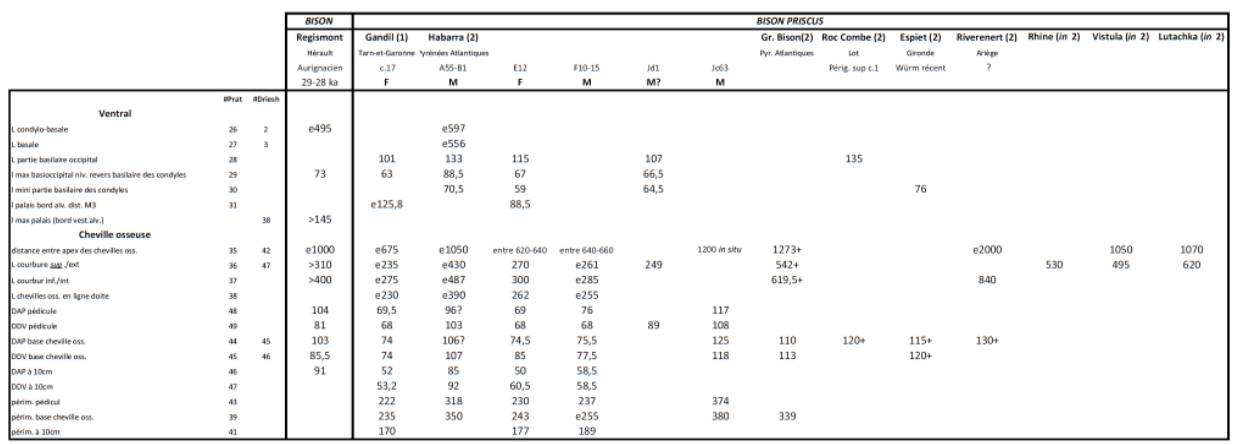

Table 2a - Fossil bison skulls from Belgium and Siberia. Dorsal, lateral and nuchal views.

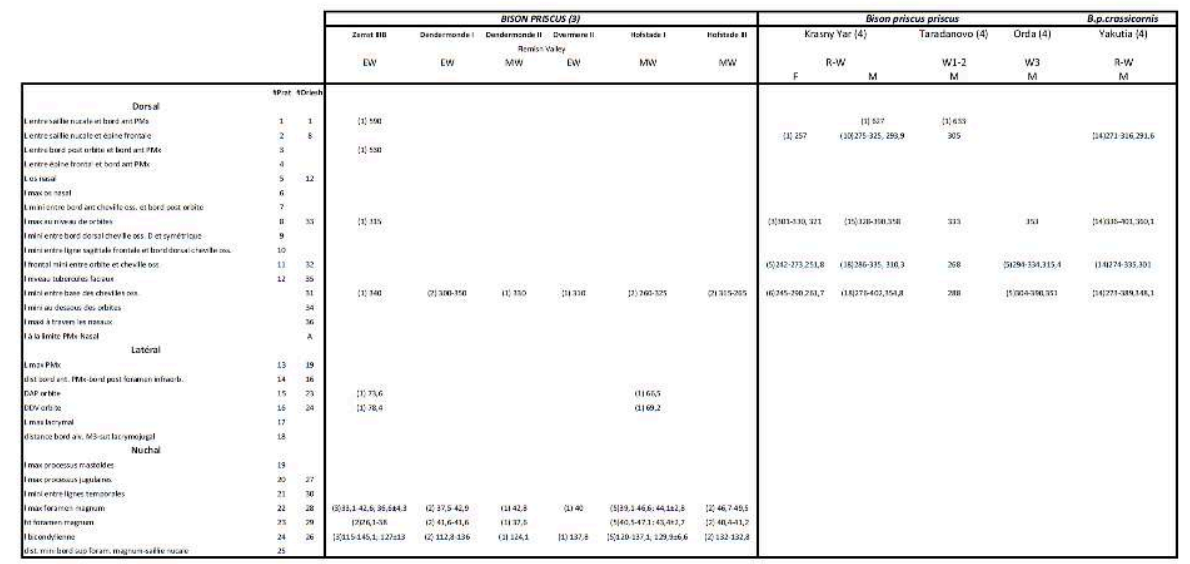

Table $2 \mathrm{~b}$ - Fossil bison skulls from Belgium and Siberia. Ventral view and horn-core.

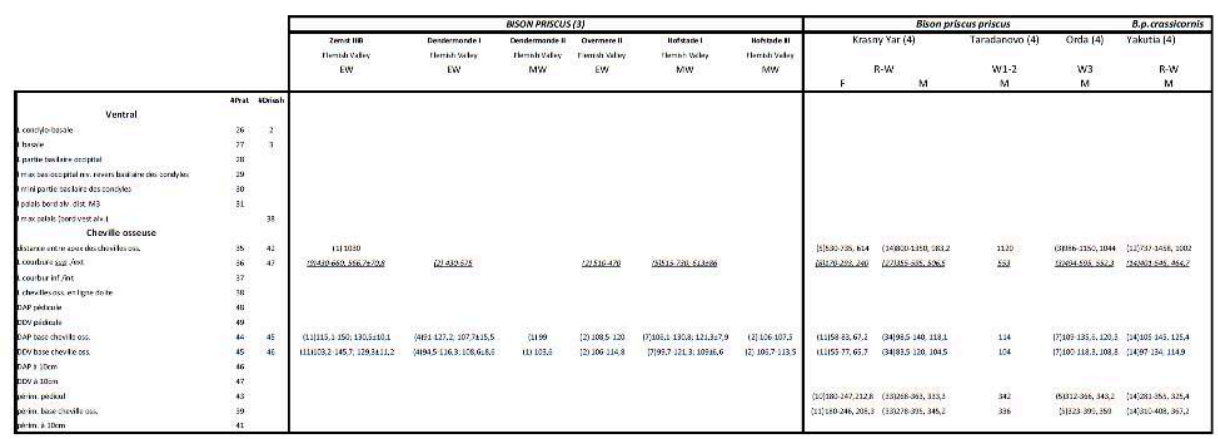


Table 3a - Modern European bison skull. Dorsal, lateral and nuchal views.

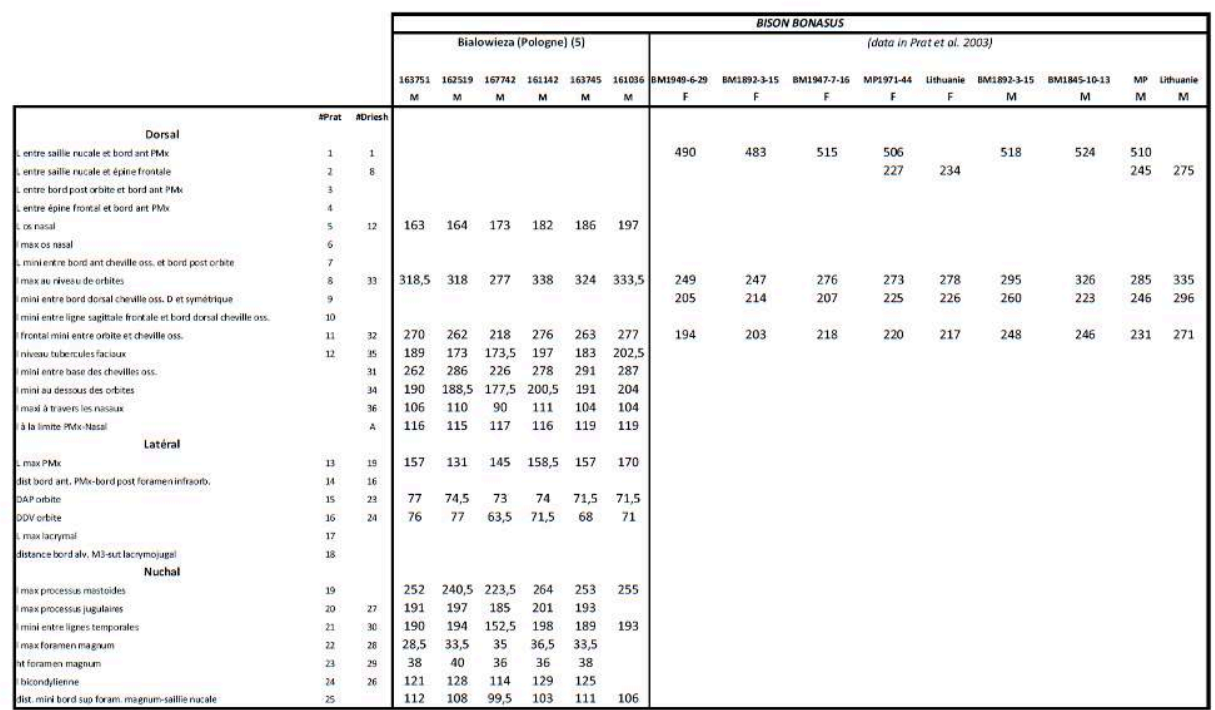

Table 3b - Modern European bison skull. Ventral view and horn-core.

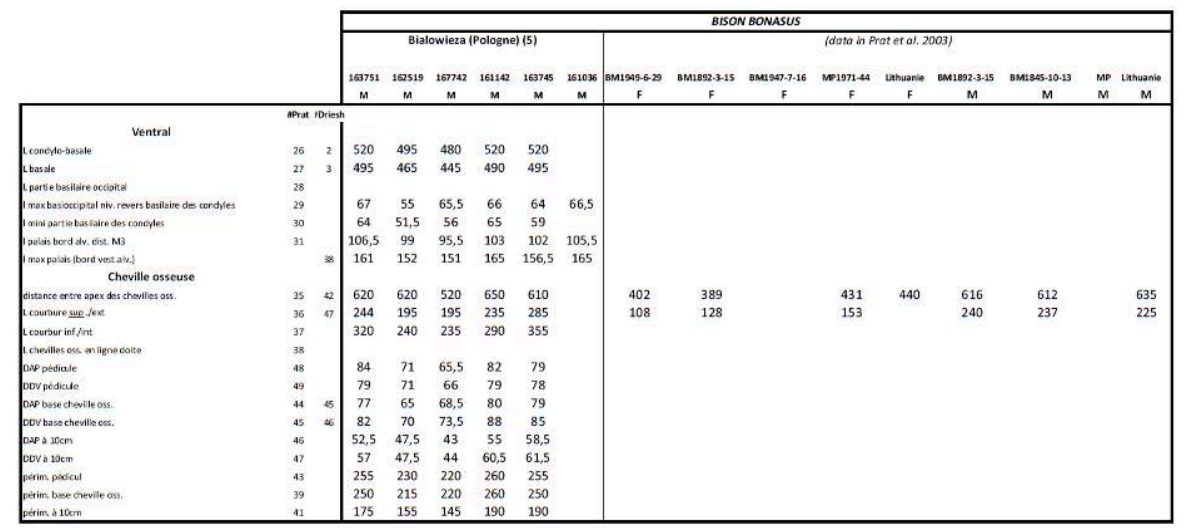

Table 4 - Complementary data from the recent Bison bonasus sample from Poland (Mammal Research Institute, Bialowieza, Poland).

\begin{tabular}{|ccccc|}
\hline $\mathbf{n}^{\circ}$ & age (ans) & sexe & Poids $(\mathbf{k g})$ & Ht garrot $(\mathbf{c m})$ \\
\hline 161036 & 12 & $\mathrm{M}$ & 790 & 187 \\
161142 & 9 & $\mathrm{M}$ & 740 & 177 \\
162519 & 5 & $\mathrm{M}$ & & \\
163745 & 7 & $\mathrm{M}$ & & \\
163751 & 6 & $\mathrm{M}$ & 650 & 180 \\
167742 & 4 & $\mathrm{M}$ & & \\
\hline
\end{tabular}


Figure 4 - Scatter-diagram of cranial measurements of bison, measurements 32 and 33 (see tab. $1-3)$. The line indicates a ratio of $100 \%$ with a circular section.

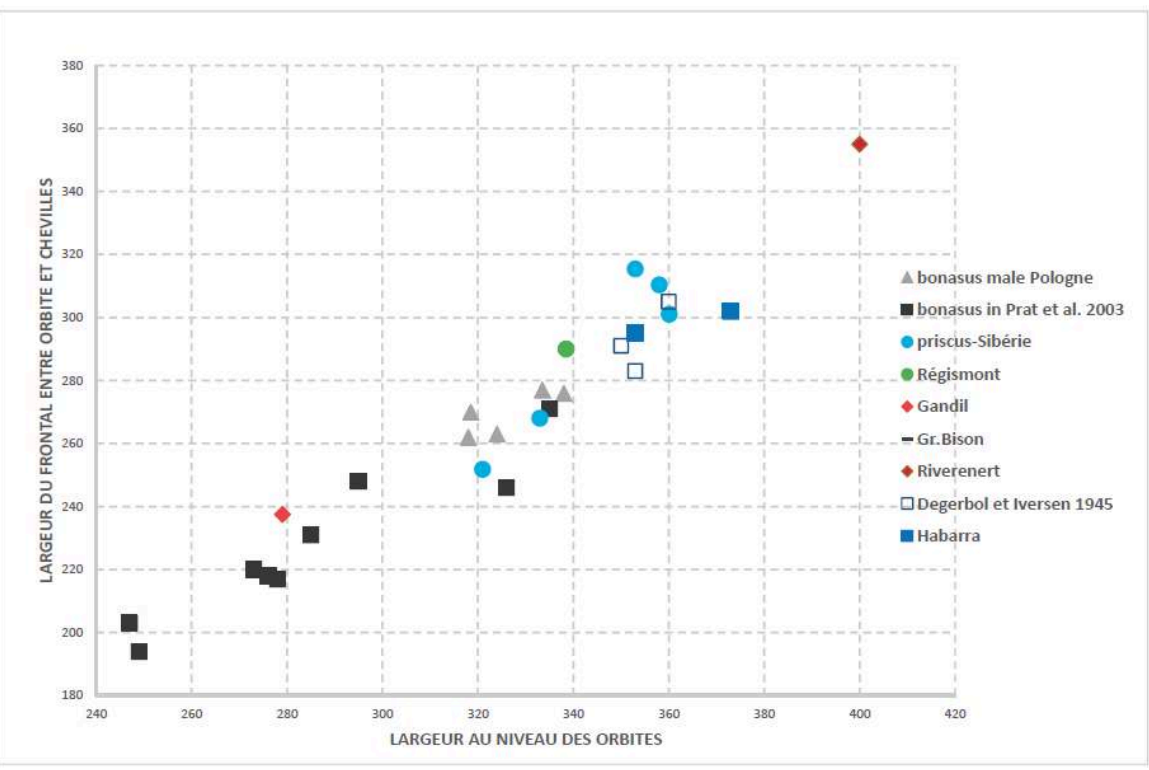

Figure 5 - Scatter-diagram of horn-core measurements of bison, measurements 45 and 46 (see tab. 1-3).

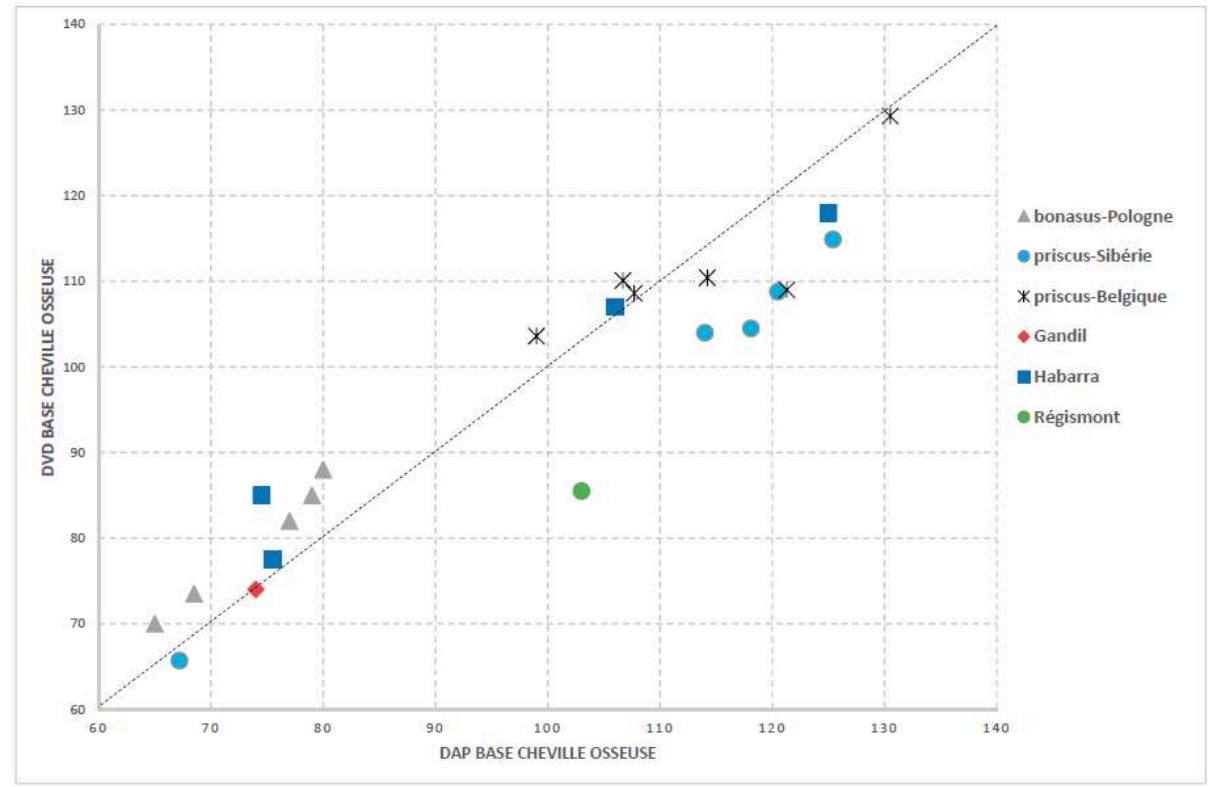

\section{Conclusions}

In this contribution, we present the history (paleo-history: Valentin 2008, 2011) of a skull discovered in the original context of an open-air camp of Aurignacian hunters. 
This history was revealed by a taphonomic and paleontological analysis which allowed us to determine the nature of the skull, and to propose a symbolic, or at least allegorical, assessment. The archaeological as well as ethnographic examples demonstrate a certain universality in these practices laden with emotions and "iconic adventures" (Otte 2016).

The Languedoc plains must have been a particularly suitable biotope for herds of bison during MIS3, in an open palaeoenvironment. They were one of the preferential game of prehistoric human groups (Brugal et al. 1999), and a major animal for them, as shown by the ornamentation of certain caves (for example, the Aurignacian of Chauvet Cave in Ardèche, Chirica 2006); the bison is an almost constant element in the Upper Palaeolithic bestiary, with a deteerminant socio-economic dimension. The abundance and permanence of this choice game in these plains are undoubtedly one of the key factors behind the installation of Aurignacian groups in this sector. The trophy-head studied here belongs to a male individual weighing between 800 and 1,000 kg (see tab. 4 for modern specimens), which represents $320-400 \mathrm{~kg}$ of meat, fat and marrow (about $40 \%$ of the living weight). This mass of meat could have fed a considerable number of people (several dozen people) for several weeks. Given the problem of the natural deterioration of meat, storage and conservation techniques may have been used, which could be linked to the high number of hearths identified at the camp, or at least in the excavated zone, accompanied by intensive hide-processing (cf. supra). For more information, we refer the reader to the archaeological and ethnographic overview proposed by J. Speth (2017) on all of the different aspects (social, economic, technological, nutritional...) of the exploitation and consumption of bison by human groups.

For the acquisition of game such as bison, we can add that a head must have weighed several dozen kilos; the abandonment of the latter near what appears to be a butchery area thus corroborates the fact that the animal must have been slaughtered in the immediate vicinity of the camp - or else the slaughter of the bison may have determined the implantation of the camp.

Finally, the many depictions of bison in Palaeolithic art (with long or shorter horns) back up, in our opinion, the symbolic interpretation proposed here. The bison is part of a range of functional (food, technical: many by-products), symbolic or spiritual roles. The Bovids, with the Equids, form an immutable "di-ade" since drawings and paintings, cynegeticaly grounded, or more, until that same couple blowing and offering their heat, and more, to a deity (creche).

History of "hecatombs 3 "...

\section{BIBLIOGRAPHY}




\section{Bibliographic references}

ANDERSON L., LEJAY M., BON F., MENSAN R., BRUGAL J.-PH., COSTAMAGNO S., HECKEL C., ARAUJO M., MÉNARD M., PRADEAU J-V., SALOMON H., SELLAMI F., BARSHAY-SZMIDT C. (soumis) - Insights into Aurignacian daily life and camp organization: the open-air site of Régismont-leHaut. Quaternary International.

BEMENT L.C. 2003 - Constructing the Cooper model of Folsom bison kills on the southern plains. Great Plains Research 13 (Spring 2003): 27-41.

BOHLKEN H. 1958 - Vergleichende Untersuchungen an Wildrindern (Tribu Bovini Simpson 1945). Zool.Jahrb.Abt., 68 : 113-202.

BON F., MENSAN R., ET COLL. DE ARAUJO IGREJA M., COSTAMAGNO S., GARDÈRE P., MÉNARD C., SELLAMI F., SZMIDT C., THÉRY-PARISOT I. 2007 - Le site de plein air de Régismont-le-Haut : une halte aurignacienne dans les plaines du Languedoc. In : Qui est l'Aurignacien ?, Aurignac, Editions Musée-forum, cahier 3, p. 53-71.

BON F., MENSAN R. ET ARAUJO IGREJA M., BRUGAL J.-PH., COSTAMAGNO S., GARDÈRE PH., KUNTZ D., SELLAMI F., SZMIDT C., THÉRY-PARISOT I. 2008 - Poilhes, Régismont-le-Haut. In : Bilan scientifique de la région Languedoc- Roussillon 2005. Ministère de la Culture et de la Communication, p. 161-163.

BRUGAL J.-P. 1994-1995 - Le Bison (Bovinae, Artiodactyla) du gisement Pléistocène moyen ancien de Durfort (Gard, France). Bull.Mus.nat.Hist.Nat., Paris, 4é sér. 16, sect.C, n²-4 : 349-381.

BRUGAL J.P. 1999 - Étude des populations de grands Bovidés européens : intérêt pour la connaissance des comportements humains au Paléolithique. In : Le Bison, gibier et moyen de subsistance des hommes du paléolithique aux paléoindiens des grandes plaines, J.-Ph. Brugal, F. David, J. Enloe, J. Jaubert (dir.), (op.cit.) : 85-103.

BRUGAL J.P., DAVID F., ENLOE J., JAUBERT J., (dir.) 1999 - Le Bison : gibier et moyen de subsistance des hommes du Paléolithique aux Paléoindiens des grandes plaines. APDCA, Antibes, 562 p. (Actes du Colloque international, Toulouse, 6-10 juin 1995).

BRUGAL J.P., FOSSE P. 2005 - Les grands bovidés (Bison cf. schoetensacki) du site pléistocène moyen de La Vayssière (Aveyron, France). Actes du Coll. Les Ongulés Holarctiques du Pliocène et du Pléistocène, E.Crégut-Bonnoure (ss.la dir.), Quaternaire, H.S. nº 2 : 75-80.

BRUGAL J.P. (coord), BEAUVAL C., COUMONT M.P., FOURNIER J., GERBE M., GRIGGO C. 2013 Stratégies d'exploitation des ressources carnées au Paléolithique moyen en Quercy. In : Modalité d'occupation et exploitation des milieux au Paléolithique dans le Sud-Ouest de la France : l'exemple du Quercy. Paleo, supplément $n^{\circ} 4$ (Actes de la session C67, XVème Congrès mondial de l'UISPP, Lisbonne, sept. 2006) : 213-229.

CHIRICA V. 2006 - Opinions concernant l'art et les religions paléolithiques sur la Base d'une grande découverte. Archeologia Moldovei, XXIX: 185-191.

COOPER A., TURNEY C., HUGHEN K.A., BROOK B.W., McDONALD H.G., BRADSHAW C.J.A. 2015 Abrupt warming events drove Late Pleistocene Holarctic megafaunal turnover. Science, 349 (6248): 602-606.

CROUZEL F., MANENC A., REVEL J-C. 1982 - Squelettes de Bison priscus Bojanus ssp gigas Flerov, 1969 dans une grotte ariégeoise. Bulletin de la Société d'Histoire naturelle de Toulouse, 118 : 71-100.

DEGERBØL M., IVERSEN J. 1945 - The Bison in Denmark. A zoological and geological investigation of the finds in Danish Pleistocene deposits. København: Danm.Geol.undersøgelse, 62p. (Publ.73). 
DRIESCH A. von den 1976 - A guide to the measurement of animal bones from archaeological sites. Peabody Museum, Harvard University Cambridge, Bull. $n^{\circ} 1,136$ p.

EMPEL W. 1962 - Morphologie des schadels von Bison bonasus (Linnaeus 1758). Acta Theriologica, 6(4): 53-111+ph.

GAMBERI ALMENDRA DE CARVALHO L., ARGANT A., ARGANT J., BARTH P., BOUDADI-MALIGNE M., BOULBES N., BRUGAL J.-P., CARAMELLI D., CONDEMI S., CRÉGUT E., DEBARD E., ERRERA M.G.L., FARRE B., FAURE M., FERNANDEZ P., GEIGL E.-M., GUÉRIN C., HARTER S., JEANNET M., LATEUR N., MALLYE J.-B., MARTIN S., MONNEY J., ROMAN C., ROUSSELIÈRES F., SABAUT M., VALLI A. 2011- L'aven de l'Arquet - Barjac (30) : étude d'un aven piège. Ardèche Archéologie, 28 : 3-10.

GARRAIT-BOURRIER A. 2006 - Spiritualité et Fois Amérindiennes. Résurgence d'une identité perdue. Cercles 15 : 98-95.

GERAADS D. 1992 - Phylogenetic analysis of the tribe Bovini (Mammalia, Artiodactyla). Zool. J. Linn. Soc. Lond. 104, 193-207.

GERAADS D. 1992 - Phylogenetic analysis of the tribe Bovini (Mammalia, Artiodactyla). Zool. J. Linn. Soc. Lond., 104, 193-207.

GERMONPRÉ M. 1993 - Osteometric data on Late Pleistocene mammals from the Flemish Valley, Belgium. Documents de travail de l'Institut Royal de Sciences Naturelles Belge, $n^{\circ} 72$ : 5-135.

GRIGGO C. 2014 - La faune magdalénienne de l'abri Gandil à Bruniquel (Tarn-et-Garonne). Etudes paléontologique, taphonomique et archéozoologique. In : L'abri Gandil à Bruniquel (Tarn-etGaronne) : un campement magdalénien du temps de Lascaux. E.Ladier (dir.), Préhistoire du Sud-Ouest, suppl. $13: 49-71$.

GROMOVA V.I., 1932 - Uber den typus des Bison priscus Boj. Zool.Anz., 99 : 207-221.

GROMOVA V.I. 1935 - Die vorweltliche Wisent (Bison priscus Bojanus) in USSR. Trav.Inst.Paleozool.Acad.Sci.URSS, 2 (2/3):77-204.

GROVES C.P. 1981 - Systematic relationship in the Bovini (Artiodactyla, Bovidae). Z.Zool.Syst.Evolutionforsch., 19/4 : 264-278.

HASSANIN A., AN J., ROPIQUET A., THANH NGUYEN T., COULOUX A. 2013 - Combining multiple autosomal introns for studying shallow phylogeny and taxonomy of Laurasiatherian mammals: Application to the tribe Bovini (Cetartiodactyla, Bovidae). Molecular Phylogenetics and Evolution, 66:766-775.

HILL A. 1979 - Disarticulation and Scattering of Mammal Skeletons. Paleobiology, (5, 3): 261-274.

HILL A., BEHRENSMEYER A.K. 1984 - Disarticulation Patterns of Some Modern East African Mammals. Paleobiology, (10, 3): 366-376.

HILL A., BEHRENSMEYER A.K. 1985 - Natural Disarticulation and Bison Butchery. American Antiquity, (50, 1): 141-145.

KUNTZ D. 2006 - Notes sur la restauration du crâne de Bison du secteur S67. Pp.51-55. In : Bon F. et al. - Régismont-le-Haut (Poilhes, Hérault). Campagne de fouilles d'un habitat de plein air aurignacien. Rapport d'opération de fouille programmée, SRA Languedoc-Roussillon, 68 p.

FLEROW C.C. 1975 - Die Bison-Reste aus den Travertinen von Weimar-Ehringsdorf.. Abh.Zentr.Geol.lnst., 23 : 171-199. 
FLEROW C.C. 1976 - Die fossilen Bisonreste von Taubach und ihre Stellung in der Entwicklungs geschichte der Gattung Bison in Europa. Quartär Paläontologie, 2 : 179-208.

FLEROW C.C. 1979 - Systematics and Evolution. In: V. E. Sokolov (Dir.), European Bison -Morphology, systematics, evolution, ecology (en russe), Moscou, Nauka, p. 9-127 (USSR Ac. of Sc.).

FRISON G.C. 1971 - The Buffalo Pound in North-Western Plains Prehistory: Site 48 CA 302, Wyoming. American Antiquity, 36(1): 77-91.

MASSILANI D., GUIMARAES S., BRUGAL J.P., BENNETT E.A.,TOKARSKA M., ARBOGAST R.A., BARYSHNIKOV G., BOESKOROV G., CASTEL J.C., DAVYDOV S., MADELAINE S., PUTELAT O., SPASSKAYA N., UERPMANN H.P., GRANGE T., GEIGL E.M. 2016 - Past climate changes, population dynamics and the origin of Bison in Europe. BMC Biology, 14: 93, DOI 10.1186/s12915-016-0317-7

McDONALD J.N. 1981 - North American Bison. Their classification and evolution. Berkeley: Univ. California, 316p.

NICHOLSON N., NICHOLSON S. 2007 - Late prehistoric ceremonial treatment of a bison skull in southwestern Manitoba. Plains Anthropologist, 52:203, 317-324, DOl: 1 0.1179/pan.2007.021

OTTE M. 2016 - Arts et pensée dans l'évolution humaine. C. R. Palevol, http://dx.doi.org/10.1016/ j.crpv.2016.05.001

PALACIO P., BERTHONAUD V., GUÉRIN C., LAMBOURDIÈRE J., MAKSUD F., PHILIPPE M., PLAIRE D., STAFFORD T., MARSOLIERKERGOAT M.C., ELALOUF J.M. 2017 - Genome data on the extinct Bison Schoetensacki establish it as a sister species of the extant European bison (Bison bonasus) BMC Evolutionary Biology 17:48.DOI 10.1186/s12862-017-0894-2.

PFEIFFER T. 1999 - Systematic relationship within the Bovini, with special reference to the fossil taxa Bos primigenius Bojanus and Bison priscus Bojanus. In : G.C. Weniger (dir), Archäologie und Biologie des Auerochsen. Neanderthal Museum, 1: 60-70.

PRAT F., DELPECH F., CANCEL N., GUADELLI J.L., SLOTT-MOLLER R. 2003 - Le Bison des steppes, Bison priscus Bojanus, 1827, de la grotte d'Habarra à Arudy (Pyrénées-Atlantiques). Paleo, cahier spécial n5: 1-102.

PILGRIM G.E. 1947 - The evolution of the buffaloes , oxen , sheep and goats. J. Linn. Soc. Lond., 279: 272-286.

REHER C.A., FRISON G.C. 1980 - The Vore site, 48ck302, A stratified buffalo jump in the Wyoming black hills. Plains Anthropologist, Memoir 16 (25): 221 p.

SALA B. 1987 - Bison schoetensacki Freud. from Isernia la Pineta (early Mid-Pleistocene, Italy) and revision of the European species of bison. Palaeontogr. Ital., 74: 113-170.

SOUBRIER J., GOWER G. CHEN K., RICHARDS S.M., LLAMAS B., MITCHELL K.J., HO S.Y.W., KOSINTSEV P., LEE M.Y., BARYSHNIKOV G., BOLLONGINO R., BOVER P., BURGER J., CHIVALL D., CREGUT-BONNOURE E., DECKER J.E., DORONICHEV V.B., DOUKA K., FORDHAM D.A., FONTANA F., FRITZ C., GLIMMERVEEN J., GOLOVANOVA L.V., GROVES C., GUERRESCHI A., HAAK W., HIGHAM T., HOFMAN, KAMINSKA E., IMMEL A., JULIEN M.A., KRAUSE J., KROTOVA O., LANGBEIN F., LARSON G., ROHRLACH A., SCHEU A., SCHNABEL R.D., TAYLOR J.F., TOKARSKA M., TOSELLO G., PLICHT J.VAN DER, LOENEN A. VAN, VIGNE J.D., WOOLEY O., ORLANDO L., KOWALCZYK R., SHAPIRO B., COOPER A. 2016 - Early cave art and ancient DNA record the origin of European bison. Nature Communications, DOI: 10.1038/ncomms13158.

SOKOLOV V.E., (Dir.) 1979 - European Bison -Morphology, systematics, evolution, ecology (en russe), Moscou, Nauka, (USSR Ac. of Sc.), 495p. 
SPASSOV N., STOYTCHEV T. 2003 - On the origin of the wisent, Bison bonasus (Linnaeus, 1758): presence of the wisent in the upper Palaeolithic art of Eurasia. Advances in Vertebrate Paleontology « Hen to Panta », 125-130.

SPETH J.D. 2017 (ss-pr) - A New Look at Old Assumptions: Paleoindian Communal Bison Hunting, Mobility, and Stone Tool Technology. In : Manipulating Prey: Development of Large-Scale Kill Events Around the Globe. K. Carlson and L. Bement (eds), University Press of Colorado, Boulder, CO: \& 8. TODD L.C., RAPSON D.J. 1999 - Formational analysis of bison bonebeds and interpretation of Paleoindian subsistence. In : Le Bison : gibier et moyen de subsistance des hommes du Paléolithique aux Paléoindiens des grandes plaines, (op.cit.): 479-499.

VALENTIN B. - 2008 - Jalons pour une paléohistoire des derniers chasseurs (VIVé-VIé millénaire avant J.C.). Publication de la Sorbonne. 329 p.

VALENTIN B. 2011 - Le Paléolithique. Presses Universitaires de France, «Que sais-je ?» $n^{\circ} 3924$.

VASILIEV S.K. 2008 - Late Pleistocene bison (Bison p. priscus Bojanus, 1827) from the southeastern part of Western Siberia. Archaeology Ethnology \& Anthropology of Eurasia 34/2: 34-56

WALL D.A., DAVIS S.K., READ B.M. 1992 - Phylogenetic relationships in the subfamily Bovinae (Mammalia: Artiodactyla) based on ribosomal DNA. J.Mamm., 73(2): 262-275.

\section{NOTES}

1. "Even though it cannot be proven, in particular by lithic refits, the hypothesis that this site corresponds to a single installation phase, forming a vast camp, seems to predominate over that of short, repetitive installations. In addition, we will see that this skull provides evidence of being covered rapidly, reducing the time required for sealing the traces at the site, while the quantity of meat from this animal could have fed a significant group - although this is still impossible to prove" (F. Bon, pers. comm.)

2. Alors que cet article était sous-presse, un papier sur un ADN fossile d'un seul os (Palacio et al. 2017), daté de 36 ky, ressuscitait un Bison schoetensacki, espèce disparaissant au début du Pléistocène moyen, et dont on ne connaît d'ailleurs pas le génome... ce qui nous paraît assez étonnant.

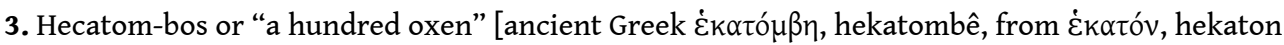
("one hundred") and ßoũc, bous ("ox"). The number of animals slain during sacrifices; term used here as a wink and many examples of mass slaughter (collective hunting) of bovines (bison, ox) mentioned from the Palaeolithic until the present-day (Brugal et al. 1999, 2013), particularly in "bison societies", where they were one of the main resources. The symbolic value of large bovids is widely acknowledged in very different societies in the northern hemisphere, from the Pleistocene and the Holocene. 


\section{ABSTRACTS}

The discovery of a Bison skull (with its atlas) in the Aurignacian site of Régismont-le-Haut (Hérault) is relatively surprising in this open-air context where faunal remains are not well preserved. Complementary studies in the fields of paleontology, taphonomy and zooarchaeology enable us to reconstruct the history (paleohistory) of this specimen and to discuss its taxonomical position, as well as its (economic, symbolic) value.

\section{INDEX}

Keywords: Bison, France, Eurasia, Taxonomy, Taphonomy, Zooarchaeology

\section{AUTHOR}

\section{JEAN-PHILIP BRUGAL}

Aix-Marseille Université, CNRS, MCC, UMR 7269 LAMPEA (Laboratoire Méditerranéen de Préhistoire, Europe-Afrique), Aix-en-Provence, France - brugal@mmsh.univ-aix.fr 